\title{
Impact of Riverbank Erosion on Population Migration and Resettlement of Bangladesh
}

\author{
Md. Shohel Rana', Ayesha Meherun Nessa ${ }^{2}$ \\ ${ }^{1}$ Department of Statistics, Noakhali Sciences and Technology University, Noakhali, Bangladesh \\ ${ }^{2}$ Department of Geography and Environment, Jahangirnagar University, Saver, Bangladesh
}

Email address:

ranashohe178@yahoo.com (Md. S. Rana),meherunju@yahoo.com (A. M. Nessa)

\section{To cite this article:}

Md. Shohel Rana, Ayesha Meherun Nessa. Impact of Riverbank Erosion on Population Migration and Resettlement of Bangladesh. Science Journal of Applied Mathematics and Statistics. Vol. 5, No. 2, 2017, pp. 60-69. doi: 10.11648/j.sjams.20170502.11

Received: August 16,2016; Accepted: August 31, 2016; Published: March 4, 2017

\begin{abstract}
This study is concerned with riverbank erosion and population migration which has more impact on Bangladesh. The study is highly subject to riverbank erosion. Origin and Destination survey method are used for finding population migration and resettlement pattern and tracking population migration and resettlement. Riverbank erosion is causing socioeconomic and environmental problems in Bangladesh. Different research had identified that people who suffered from riverbank erosion ended up as landless migrated people and this migration is a major contributory factor to recurrent poverty in Bangladesh. The study was found that two-third people migrate permanently one union to another union because they get support from their neighbors, relatives, friends and they also stay here due to low living cost comparatively another area. There are no specific policies to rehabilitate the erosion-hit people. Thus, it is time to formulate policies to address prevention of riverbank erosion as well as to rehabilitate the river-erosion migrants.
\end{abstract}

Keywords: Erosion, Impact, Migration and Resettlement

\section{Introduction}

The geographical position of Bangladesh is between the Himalayas and the Bay of Bengal together with the prevalence of tropical monsoon climate. The major three rivers: the Ganges- Padma, the Brahmaputra-Jamuna and the Meghna with their innumerable tributaries and distributaries form the characteristic features of the Bengal delta, most of which is occupied by Bangladesh. The catchment area of the major rivers is about 1.65 million square $\mathrm{km}$ of which only 7.5 percent lies within the border of Bangladesh that generates $1200 \mathrm{~km}^{3}$ of run-off annually, only 10 percent of which is generated within Bangladesh (Sarker et al., 2003). In addition to vast quantities of water, these rivers carry out about 1.1 billion tons of sediment every year (EGIS, 2000; Sarker et al., 2003) and are responsible for the prevalence of flooding and riverbank erosion in Bangladesh (Elahi, 1991).

It is estimated that more than half ( 52 percent) of rural population are functionally landless and they have limited opportunity to cultivate their tiny land with more than two crops in a calendar year. In such a condition, any loss of land by a household is devastating. Annual inundation brings moisture, silt, and fertile soil for simple agriculture; but abnormal flooding and rapid riverbank shifts seriously disrupt human settlement and activities. The socioeconomic impacts of riverbank erosion are sticking as the numbers of marginalized peoples are increasing day by day. Riverbank erosion has become a common phenomenon along with the major and minor rivers in Bangladesh mainly due to deltaic topography and it has been forcing people to migrate or resettle in areas which is more vulnerable. The annual flooding due to presence of Jamuna River is a blessing because it makes the land fertile but the magnitude of flood waters regularly causes riverbank erosion. As the consequences, every year a sizeable population is affected by erosion. People not only loss their houses and agricultural lands but also become displaced often permanently and impoverished. The present study deals with the population migration and resettlement due to the environmental problem like riverbank erosion.

Environmental migrants are one of the most burning issues at this time throughout the world. As Bangladesh is a land of rivers, it is suffering from severe riverbank erosion which 
compels thousands of people to be displaced from their place of origin. The major rivers e.g., the Padma, the Jamuna and the Meghna erode several thousand hectares of floodplain making thousands of people landless and homeless every year. No other disaster is as disastrous as riverbank erosion and internally migrated populations face many unavoidable problems at different stages of migration. Migration marginalized them in respect of livelihood and forced to lead a floating life.

The main aim of this study is to a better understanding of the impact of riverbank erosion on population migration and resettlement. To achieve the aim of the research, the following objectives are considered:

a To assess the riverbank erosion scenario of Bangladesh.

$b$ To find out the migration and resettlement patterns of Bangladesh.

c To assess the livelihood condition of the migrated people.

\section{Literature Review}

Elahi (1972), Islam (1976) and Khan (1982) calculated that the rate of urbanization has been increasing by more than 60 percent per decade since the independence of Bangladesh, which is mainly attributed to rural-urban migration rather than a natural increase in urban population. It was observed that such increase has caused escalating the growth of slums and squatters in many urban centres (Hutton and Haque, 2004). One quarter of slum dwellers migrated from rural areas to urban centres particularly in Dhaka city because of the uprooting caused by natural disasters (Akhter, 1984) and almostone-tenth of the riverbank erosion induced marginalized people to migrate in urban centre in searching for livelihood option (Hossain, 1984).

Saint and William (1980) mentioned in their study that migration is a social process conditioned by changes in the structure of the economy and that of the society. His arguments direct us to conclude that the migration is a kind of movement that can make a change in technology and the organization of production may reduce rural labor requirements.

Haque (1987) discussed the general impacts of hazards in the Lower Brahmaputra (Jamuna) floodplain of Bangladesh. The impacts of bank erosion hazards have been assessed in terms of loss of land, change in occupation, and impacts on social ties and relationships. The basis of analysis of impacted was a survey conducted on 547 randomly selected displaces households. It is indicated that a large number of household who had agriculture as their primary occupations became labor following dislocation by the bank erosion hazard. The paper concluded that some social measure should be undertaken to ameliorate this problem.

In 1990, the IPCC declared that the greatest single consequence of climate change could be migration, "with millions of people displaced by shoreline erosion, coastal flooding and severe drought'. In the mid-1990s, Norman Myers became the most prominent proponent of this 'maximalist' school (Suhrke, 1993), stating that there were 25 million environmental refugees in the mid-1990s, and claiming that this figure could double by 2015 , with an upper limit of 200 million by 2050 due to desertification, lack of water, sanitation of irrigated lands and the depletion of biodiversity and (Myers, 1997). It also has been hypothesized that displacement would amount to $30 \mathrm{~m}$ in China, $30 \mathrm{~m}$ in India, $15 \mathrm{~m}$ in Bangladesh, $14 \mathrm{~m}$ in Egypt, $10 \mathrm{~m}$ in other delta areas and coastal zones, $1 \mathrm{~m}$ in island states, and with otherwise agriculturally displaced people totaling $50 \mathrm{~m}$ by 2050 (Myers and Kent, 1995), the figure might be as high as 200-250 million (Stern, 2006; Christian Aid, 2007). Sea level rise may impose vulnerability on the low-lying areas (case for Bangladesh, Vietnam and India) and existence of those communities (Agrawala et al., 2003; Abrar and Azad, 2004; Stern, 2006).

Alam (1990) emphasizes on the Char land which has a good prospect for addressing the problem on landlessness by a planned programme of land distribution. It is pointed out that a large amount of land, which emerged as a result of riverbank erosion, needs proper survey in order to bring this land within government control. It is shown how through selective violence a few land grabbers maintain control over Char land and settlement. The paper cited examples how government backed programme for the distribution of land to landless has been threatened by the unscrupulous jotedars in collaboration with the local politicians and dishonest officials.

Mahmood (1992) defined migration as an act of people's movement to a foreign country for a particular period of time, and with a definite purpose in mind. The concept of migration, however, should be clearly understood. Meyer and Clyed (1967) has distinguished between mobility, represent movement within boundaries, and migration, in which persons cross their boundaries. Such boundaries may be geographical, structural, ethnic or some other divisions, which is recognized by the actor as setting him apart to it. When a person migrates to the city he is facing a challenge of mobility within the new setting and new environment. This mobility may require a new life style, new attitudes, and new behavioral forms. Just as the migrant has been socialized into his rural life ways, of life, so after moving from different place, he now must learn the new social structure of the city. Most of the writers who define migration tend to speak only of the physical transition from one geographical area to another. Thus distinguished between migrations which are based on choice and those which are involuntary, but accepts for his definition simply indicates that the movement of a person's involving a permanent change of radiance. Tanjinul Hoque Mollah and Jannatual Ferdaush (2015) identify the number of climate included migrats in kazipurupazila under Sirajgonj district. They considered observed risk such as river bank erosion as casual factors of rural vulnerability.

Permanent migration is usually local or regional and not international such as a move to less affected places within the region (Hunter 2005), however, locally and regionally unplanned relocation may not be possible if the surrounding 
area is already densely populated or not accepted for resettlement (Adamo, 2008) or it seems to be high mobility or uncertainty that people are not interested for permanent migration. So far very little research has been conducted to find out nature of population displacement linked with climate change (Siddiqui, 2010) and environmental change. Even the nature of temporary migration was not well researched. Migration is a mechanism of people to manage the risk associated with vulnerability but the explicit and decisive causal linkages with migration are difficult to identify (Laczko and Aghazarm, 2009). In most of the cases in the rural areas, adaptation or mitigation and preparedness measures are inadequate to support in sustaining livelihoods and adaptive capacity of major portion of the landless people. Building resilience through adaptation at the local level often high priority for people, however when it fails people choose to migrate. So rather consider migration as threat to security, it can also represent a positive and legitimate livelihood strategy (Walsham, 2010), thus reduce poverty and risk associated with local vulnerability.

\section{Statistical Analysis}

An econometric model like multiple regression and correlation method considered as a methodology of the study. Moreover, geo-processing is a GIS operation used to manipulate spatial data. A typical geo-processing operation takes an input dataset, performs an operation on that dataset, and returns the result of the operation as an output dataset. Geo-processing operations include geographic feature overlay, feature selection and analysis, topology processing, raster processing, and data conversion. Geo-processing allows for definition, management, and analysis of information used to form decisions. Different types of geoprocessing are used in manipulating processing GIS data. Different types of geo-processing are shown below:

\section{About Dissolve}

This operation aggregates features that have the same value for an attribute that you specify.

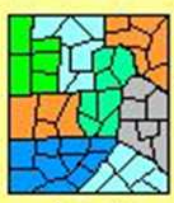

Input

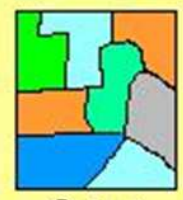

Output

\section{About Merge}

This operation appends the features of two or more themes into a single theme. Attributes will be retained if they have the same name.

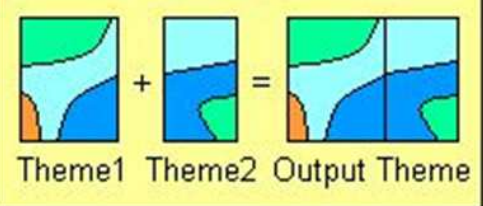

\section{About Intersect}

This operation cuts an input theme with the features from an overlay theme to produce an output theme with features that have attribute data from both themes.

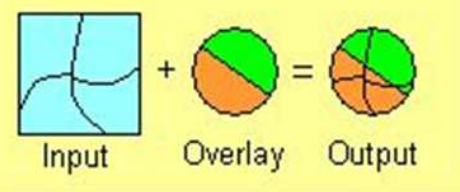

\section{About Union}

This operation combines features of an input theme with the polygons from an overlay theme to produce an output theme that contains the attributes and full extent of both themes.

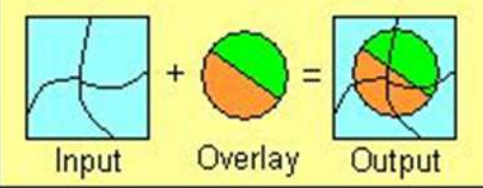

\section{About Assign Data By Location}

This operation joins only the data for features of Theme 2 to the features of theme 1 which share the same location.
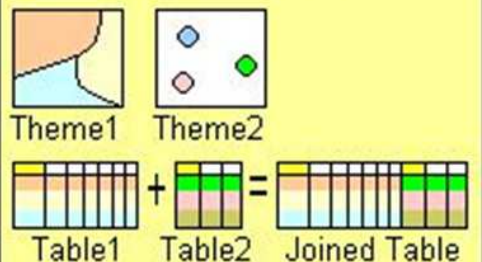

Source: http://geology.wlu.edu/harbor/geol260/lecture_notes/notes_spatial5.html

Figure 1. Different types of geo-processing.

Riverbank Erosion $=\mathrm{a}+\propto_{1}$ Population Migration $+\propto_{2}$ Resettlement $+\mathrm{e}$

$$
\mathrm{Y}=\mathrm{a}+\propto_{1} \mathrm{X} 1+\propto_{2} \mathrm{X} 2+\mathrm{e}
$$

Table 1. Coefficients of Population Migration and Resettlement.

\begin{tabular}{lllllll}
\hline \multirow{2}{*}{ Model } & & \multicolumn{2}{c}{ Unstandardized Coefficients } & Standardized Coefficients & \multirow{2}{*}{ t } & \\
\cline { 2 - 6 } & & B & Std. Error & Beta & .847 \\
\multirow{2}{*}{1} & (Constant) & .910 & 1.075 & & 1.846 & .402 \\
& MIG_P & .832 & .450 & .272 & .071 & .606 \\
\hline
\end{tabular}


or, $\mathrm{Y}=0.91+0.83 \mathrm{X} 1+0.11 \mathrm{X} 2$

Comments: If we change one unit of Population Migration, Riverbank Erosion would be change 0.83 units, again if change one unit of Resettlement, Riverbank Erosion would be change on an average 0.11 unit.

\section{Causes of Riverbank Erosion}

Riverbank erosion occurs primarily through a combination of three mechanisms: sub-aerial weakening and weathering, fluvial erosion, and mass failure. Sub-aerial processes are often viewed as 'preparatory' processes, weakening the bank prior to fluvial erosion (Mengoni and Mosselman, 2006). Sub-aerial processes dominate in the upper reaches, fluvial erosion in the middle, and mass failure in the lower reaches of a river.

Fluvial erosion is the detachment of particles from the bank surface by the direct action of the flowing water; mass failure is the collapse of bank material under the action of gravity; weakening processes are modifications of soil characteristics that increase bank erodibility, and thus induce bank erosion. Generally, the process of declination of bank line in the major river channels can be attributed to both the liquification and flowage of bank line, or to the shearing away of bank material. Such erosion process takes place both during the flood and the low flow season. In the low flow
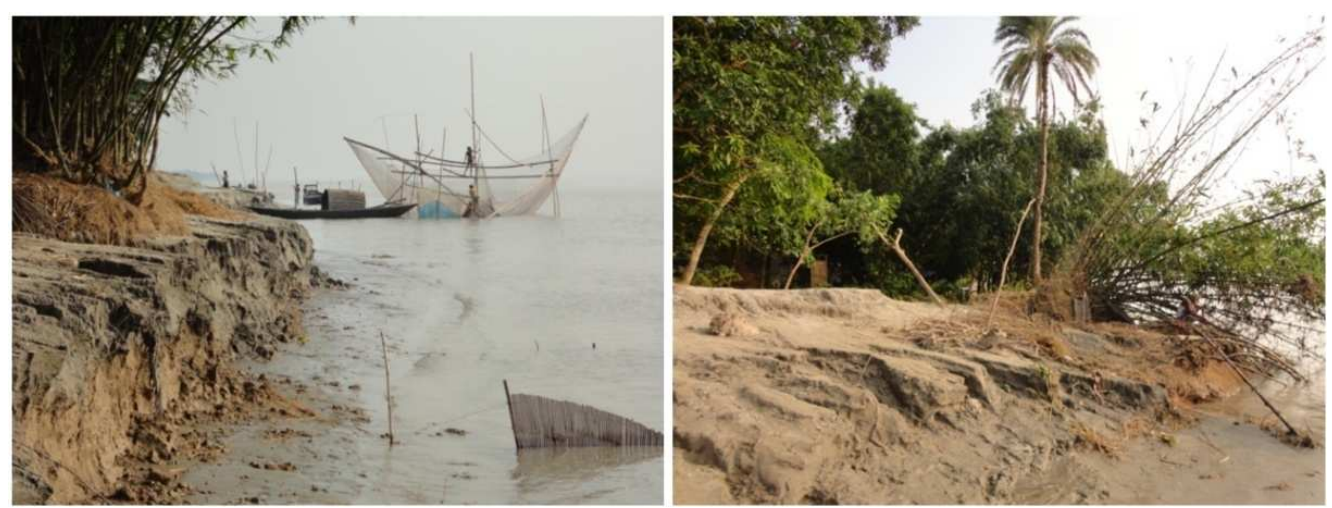

(a)
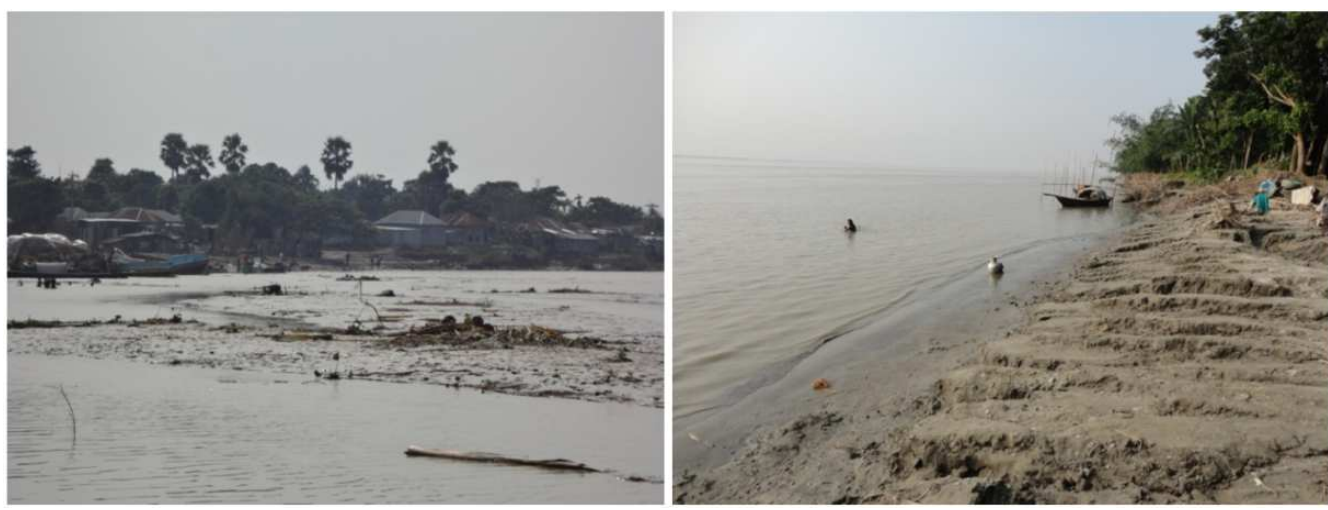

(b)

Source: Field survey, 2015

Figure 2. (a) Mass wasting and (b) erosion nearby study area. 


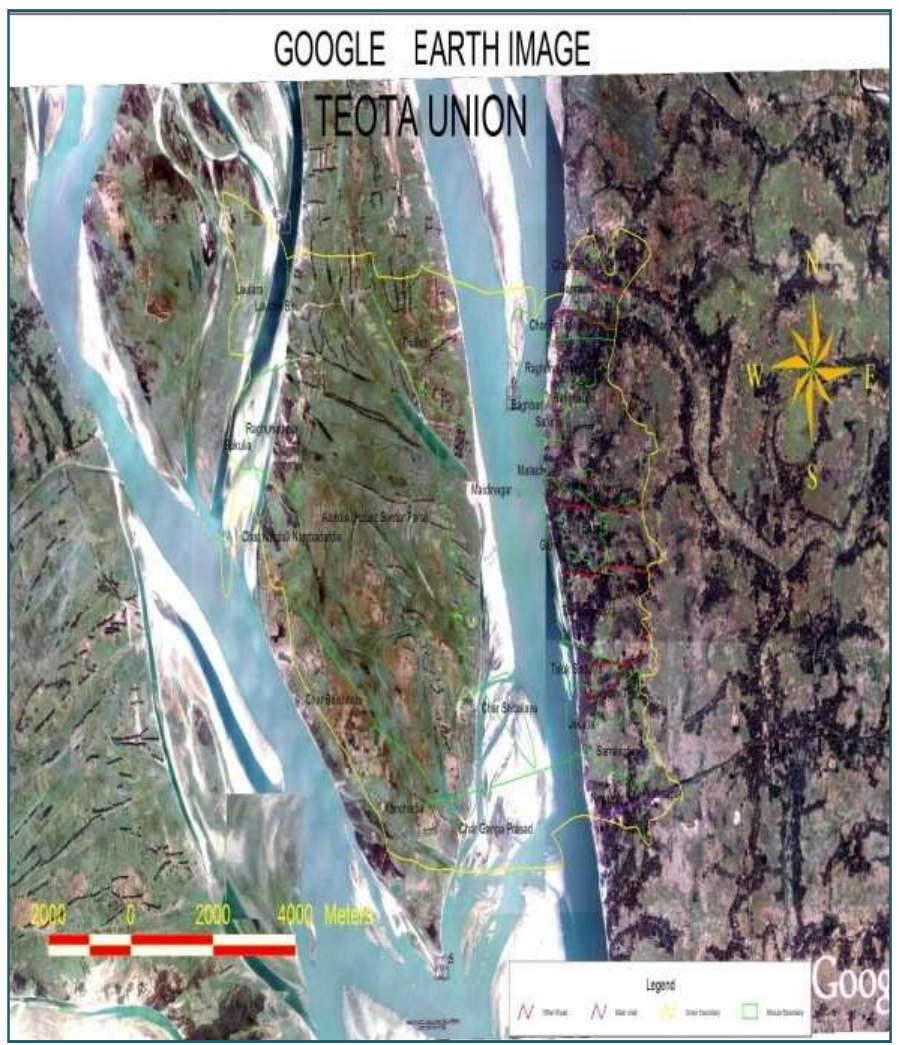

Figure 3. Present erosion scenario of Teota union.

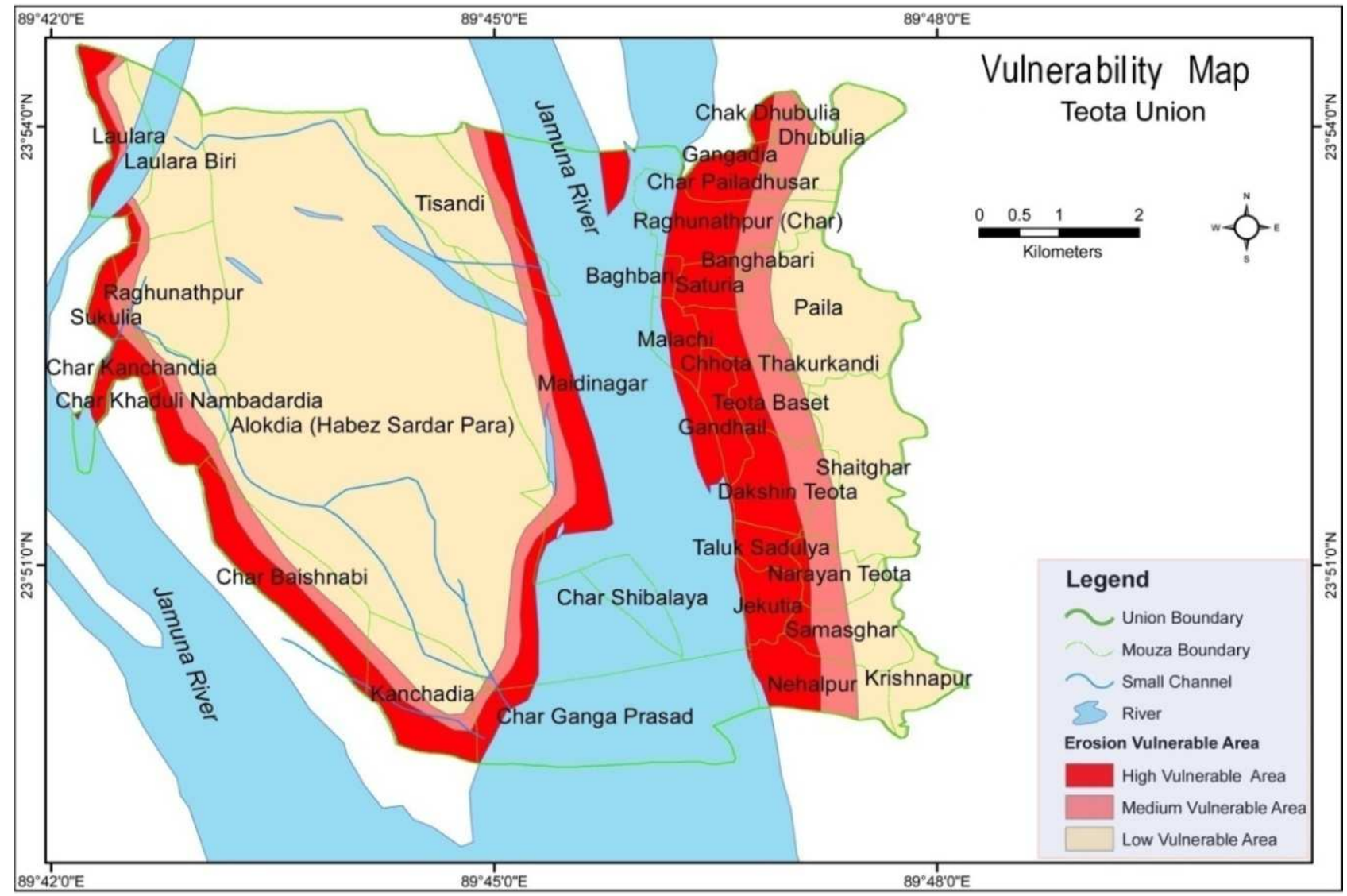

Source: Small area atlas Manikganj district, Google Earth 2015, Field Survey, 2015

Figure 4. Vulnerability map of Teota union. 


\section{Socio-economic Conditions of Riverbank Erosion Area of Bangladesh}

\subsection{Gender}

Table 2. Frequency distribution of gender variable.

\begin{tabular}{llllll}
\hline & & Frequency & Percent & Valid Percent & Cumulative Percent \\
\hline \multirow{3}{*}{ Valid } & male & 34 & 68.0 & 68.0 & 68.0 \\
& female & 16 & 32.0 & 32.0 & 100.0 \\
& Total & 50 & 100.0 & 100.0 & \\
\hline
\end{tabular}

There are about $68.0 \%$ population of the district are male whereas female is $32.0 \%$.

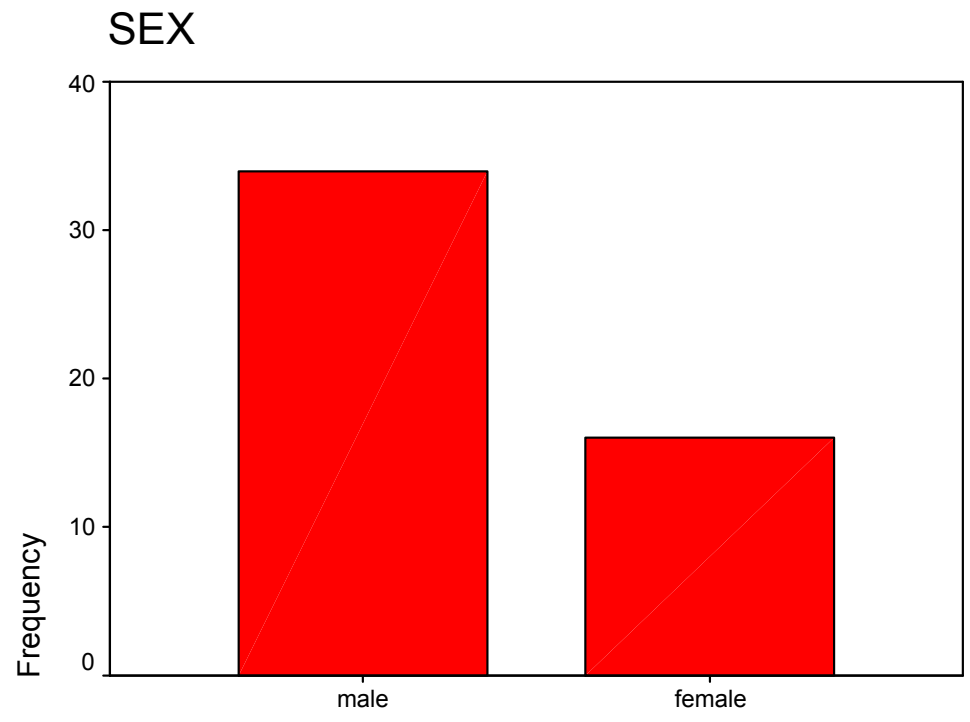

SEX

Figure 5. Bar diagram of gender respondents.

\subsection{Education}

Table 3. Frequency distribution of education.

\begin{tabular}{llllll}
\hline & & Frequency & Percent & Valid Percent & Cumulative Percent \\
\hline \multirow{4}{*}{ Valid } & 1.00 & 20 & 40.0 & 40.0 & 40.0 \\
& 2.00 & 28 & 56.0 & 56.0 & 96.0 \\
& 3.00 & 1 & 2.0 & 2.0 & 98.2 \\
& 4.00 & 2.0 & 2.0 & 100.0 \\
\hline
\end{tabular}

There are about $60.0 \%$ population of the district are literate whereas $40.0 \%$ population are illiterate at riverbank erosion area.

\subsection{Occupation}

Table 4. Frequency distribution of occupation.

\begin{tabular}{llllll}
\hline & & Frequency & Percent & Valid Percent & Cumulative Percent \\
\hline & farmer & 14 & 28.0 & 28.0 & 28.0 \\
& business & 8 & 16.0 & 16.0 & 44.0 \\
Valid & rickshaw & 6 & 12.0 & 12.0 & 56.0 \\
& fisherman & 8 & 16.0 & 16.0 & 72.0 \\
& service & 11 & 6.0 & 6.0 & 78.0 \\
& others & 50 & 22.0 & 2.0 & 100.0 \\
& Total & 100.0 & 100.0 & \\
\hline
\end{tabular}

There are about $28.0 \%$ population of the district are farmer, $16.0 \%$ are business, $12.0 \%$ are rickshaw holder, $16.0 \%$ are fisherman and only $6.0 \%$ are govt. service. 


\subsection{Permanent Settler}

Table 5. Frequency distribution of Permanent settler.

\begin{tabular}{llllll}
\hline & & Frequency & Percent & Valid Percent & Cumulative Percent \\
\hline \multirow{3}{*}{ Valid } & yes & 41 & 82.0 & 82.0 & 82.0 \\
& no & 9 & 18.0 & 18.0 & 100.0 \\
\hline
\end{tabular}

\subsection{Resettlement}

Table 6. Frequency distribution of Resettlement.

\begin{tabular}{|c|c|c|c|c|c|}
\hline & & Frequency & Percent & Valid Percent & Cumulative Percent \\
\hline \multirow{5}{*}{ Valid } & loss of homestead & 10 & 20.0 & 20.0 & 20.0 \\
\hline & employment facilities & 5 & 10.0 & 10.0 & 30.0 \\
\hline & erosion free area & 25 & 50.0 & 50.0 & 80.0 \\
\hline & homestead facilities & 10 & 20.0 & 20.0 & 100.0 \\
\hline & Total & 50 & 100.0 & 100.0 & \\
\hline
\end{tabular}

\subsection{How Many Times Migrate}

Table 7. Frequency distribution of Times Migrate.

\begin{tabular}{llllll}
\hline & & Frequency & Percent & Valid Percent & Cumulative Percent \\
\hline \multirow{4}{*}{ Valid } & two times & 25 & 50.0 & 50.0 & 50.0 \\
& three times & 19 & 38.0 & 12.0 & 38.0 \\
& four times & 6 & 100.0 & 12.0 & 100.0 \\
& Total & 50 & 100.0 & \\
\hline
\end{tabular}

Maximum people $(50.0 \%)$ migrate two times from one place to other.

\subsection{Drinking Water}

Table 8. Frequency distribution of Drinking Water.

\begin{tabular}{llllll}
\hline & & Frequency & Percent & Valid Percent \\
\hline & piped water & 1 & 2.0 & 2.0 & 18.0 \\
Valid & dug well & 9 & 18.0 & 2.0 & 20.0 \\
& rain water & 2 & 4.0 & 7.0 & 76.0 \\
& surface water & 38 & 10.0 & 24.0 & 100.0 \\
\hline
\end{tabular}

$2.0 \%$ of the population use piped water, $18.0 \%$ are use dug well, $4.0 \%$ use rain water and 7

$6.0 \%$ of the district people are use surface water.

\subsection{Causes of Riverbank Erosion}

Table 9. Frequency distribution of Causes of Riverbank Erosion.

\begin{tabular}{|c|c|c|c|c|c|}
\hline & & Frequency & Percent & Valid Percent & Cumulative Percent \\
\hline \multirow{6}{*}{ Valid } & will of god & 12 & 24.0 & 24.0 & 24.0 \\
\hline & abnormal flood & 5 & 10.0 & 10.0 & 34.0 \\
\hline & absence of embankment & 25 & 50.0 & 50.0 & 84.0 \\
\hline & excessive rainfall & 2 & 4.0 & 4.0 & 88.0 \\
\hline & changes of river courses & 6 & 12.0 & 12.0 & 100.0 \\
\hline & Total & 50 & 100.0 & 100.0 & \\
\hline
\end{tabular}

The perception of the causes of erosion has been examined on the information gathered from the study group of affected migrants. Interestingly, 24 percent migrants said that will of God is the main cause of riverbank erosion. However, the respondents cited different causes responsible for erosion of which about 50 percent mentioned the absence of embankment as an important contributory factor to bank erosion, 12 percent mentioned changes in river courses and about 10 percent viewed it as the abnormal flood. 


\subsection{How Can Stop the Riverbank Erosion}

Table 10. Frequency distribution of Stop the Riverbank Erosion.

\begin{tabular}{llllll}
\hline & Frequency & Percent & Valid Percent & Cumulative Percent \\
\hline \multirow{4}{*}{ Valid } & construction of embankment & 28 & 56.0 & 56.0 & 56.0 \\
& the channel bed & 13 & 26.0 & 26.0 & 82.0 \\
& setting blocks & 2 & 4.0 & 4.0 & 86.0 \\
& impossible to check erosion & 3 & 6.0 & 6.0 & 92.0 \\
& non response & 4 & 8.0 & 8.0 & 100.0 \\
& Total & 50 & 100.0 & 100.0 & \\
\hline
\end{tabular}

56 percent migrants said that stop the riverbank erosion by construction of embankment. However, the respondents cited different stop for erosion of which about 26 percent mentioned the dredging and deepening channel bed as an important stop factor to bank erosion, 4 percent mentioned stop the riverbank erosion by setting block and about 8 percent viewed it as the non response.

\subsection{Graphical Presentation}

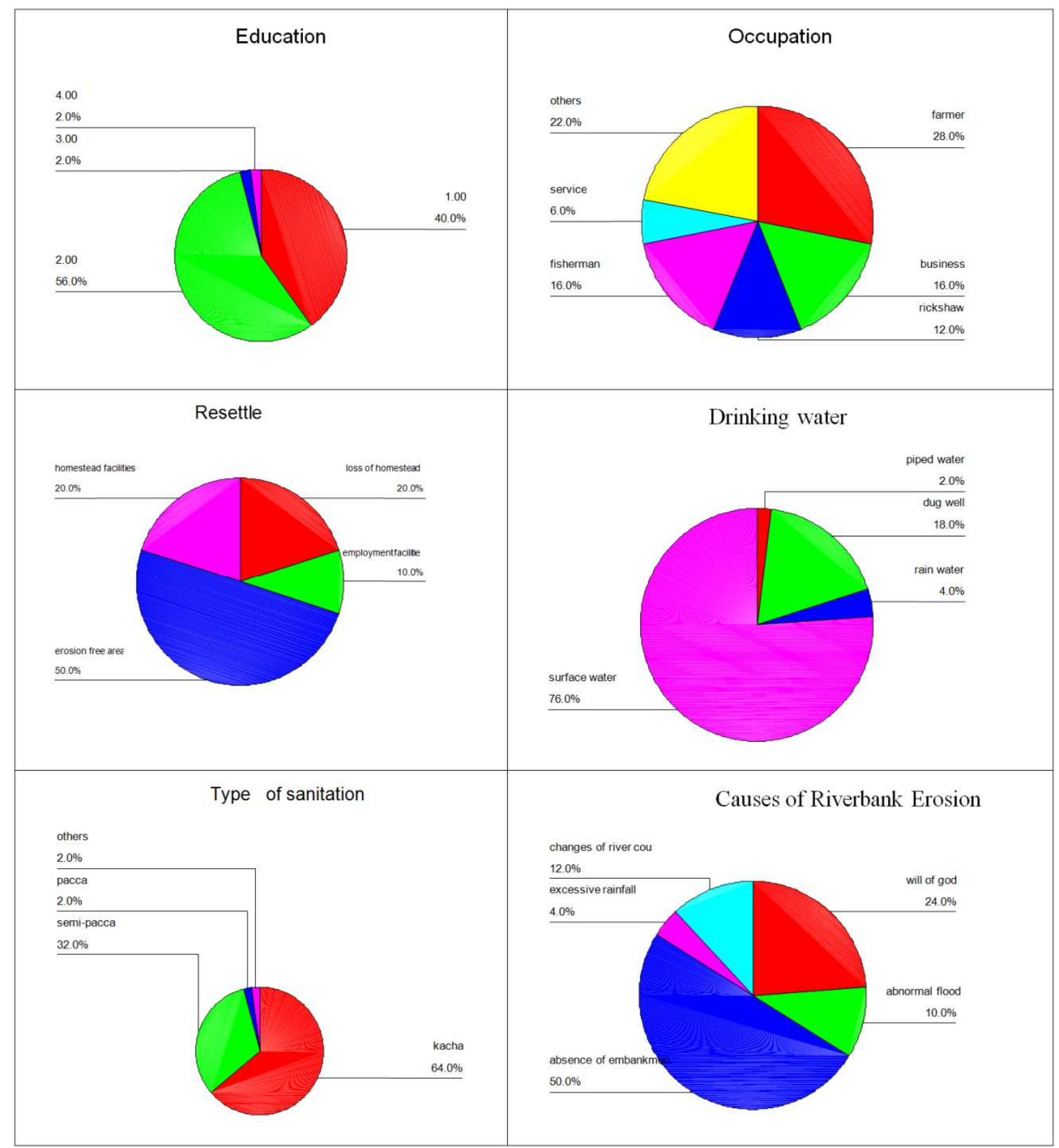

Figure 6. Pie diagram of different variable of riverbank erosion. 
Comment: The most of the people of Teota union are landless and their income is insufficient. So they are unable to maintain sanitation and hygiene. About $64.0 \%$ people use kacha latrine and $32.0 \%$ semi-pacca because many of them are live in others land.

\section{Conclusion}

The study presents a detailed investigation of riverbank erosion and population migration of Bangladesh. The people and resources of the country are under the threat of riverbank erosion due to its geographic and geologic settings and every year hundreds of people migrated from the study area with no source of food and shelter. It is common in Bangladesh that the victims of riverbank erosion do not receive same response from the concerned authorities as received by the victims of flood, tornado and cyclone- who have secured important places in the list of disasters. Because of its slow process and scattered incidences, migrants of riverbank erosion fail to draw attention successfully of the responsible authorities. Riverbank erosion and migrants do not obtain also such media coverage as victims of other disasters get. As a result, almost a silent catastrophe is going on throughout the year to that unfortunate group of people. But there is no specific policy or program for the riverbank erosion migrants either in government or in nongovernment sectors. Riverbank erosion victims are not treated in same manner by the government as victims of other disasters. Government has issued general principles for distribution of relief goods to the victims of disasters, which leaves unequal opportunities for the migrants due to few conditions for getting relief goods. Problem also lies in selecting victim families. There is no temporary shelter for riverbank erosion victims or no early warning system or no early evacuation process to evacuate the inhabitants of erosion horizontal areas. As a result, after losing homestead, migrants leave the area on their own initiatives to distant safer places. Field level experience shows that most of them move to different administrative area. So, the officials of their original area cannot assist them and the officials of resettled area have limited scope to help them as they are not the victims of that administrative area. The consequence is that, these environmental refugees become more vulnerable in every sense and compel to live under the extreme poverty line. Therefore, some changes are needed in existing policies and initiatives of institutions to work for the victims of riverbank erosion. It is needed to consider riverbank erosion as a unique environmental disaster.

\section{References}

[1] Adamo, S. B. (2008), Addressing Environmentally Induced Population Displacements: A Delicate Task. Background Paper. In, Population-Environment Research Network Cyber Seminar on Environmentally Induced Population Displacements held on August 18-29.
[2] Agrawala, S., Ota, T., Ahmed, A. U, Smith, J. and van Aalst, M. (2003), Development and Climate Change in Bangladesh: Focus on Coastal Flooding and the Sundarbans. Working Party on Global and Structural Policies, Organization for Economic Cooperation and Development, Paris.

[3] Akhter, R., (1984), Causes and Consequences of Migration to the City: A Case Study of Slum Dwellers in Dhaka, Unpublished Manuscript, Centre for Urban Studies, Bangladesh.

[4] Alam, S. M. Nurul (1990), Perceptions of Flood Among Bangladeshi Villagers. Disasters 14 (4): 354-357.

[5] BBS, 2000-2001. Statistical Yearbook of Bangladesh, Dhaka: Bangladesh Bureau of Statistics.

[6] Bangladesh Bureau of Statistics (BBS), (2003b), Bangladesh Population Census. National Vol., Bureau of Statistics, Ministry of Planning, Government of Bangladesh, Dhaka.

[7] Bangladesh Bureau of Statistics (BBS), (2005), Population Census 2001-Community Series, Shibalaya, Manikganj.

[8] Christian Aid (2007), Human Tide: The Real Migration Crisis. Retrieved from http: //www.christianaid.org.uk/Images/human-tide.pdf on June 12, 2011.

[9] EGIS, (2000), Riverine Chars in Bangladesh: Environmental Dynamics and Management Issues, the University Press Limited, Dhaka, Bangladesh, pp. 88.

[10] Elahi, K. M., (1972), Urbanization in Bangladesh: A Geodemographic Study, Oriental Geographer 16 (1): 39-48.

[11] Elahi, K. M, Ahmed, Q. S. and Mafizuddin, M (eds.), (1991), Riverbank Erosion, Flood and Population Displacement in Bangladesh. Riverbank Erosion Impact Study, Jahangirnagar University, Savar, Dhaka.

[12] Haque, Chowdhury Emdadul (1987), Impact of Riverbank Erosion in Kazipur: An Application of Landsat Imagery. REIS Newsletters, Jahangirnagar University: Savar.

[13] Hossain, M. Z., (1984), Riverbank Erosion and Population Displacement: A Case of Kazipur in Pabna. Unpublished thesis, Jahangirnagar University, Savar, Dhaka.

[14] Hunter, L. M.(2005), Migration and environmental hazards. Population and Environment 26 (4): 273-302.

[15] Hutton, D. and Haque, C., 2004, Human Vulnerability, Dislocation and Resettlement: Adaptation Processes of Riverbank Erosion-induced Displacees in Bangladesh, Disasters 28 (1): 41-62.

[16] Islam, N., (1976), The Urban Poor in Bangladesh, Centre for Urban Studies, Dhaka.

[17] Khan, A. A. M, (1982), Rural-Urban Migration and Urbanization in Bangladesh, The Geographical Review, 72 (4): 379-394.

[18] Laczko, F. and Aghazarm, C. (2009), Migration, the Environment and Climate Change: Assessing the Evidence. International Organization for Migration, Geneva.

[19] Mahmood, R. (1992), Bangladeshi Returned Migrants from the Middle East: Process, Achievement. 
[20] Mayer, H. M. and K. Clyde (1967), Reading Urban Geography, Allahabad: Central Book Depot.

[21] Mengoni, B. and Mosselman, E., (2006), Analysis of Riverbank Erosion Processes: Cecina River, Italy, River, Coastal and Estuarine Morphodynamics: RCEM 2005, Parker and Garcia (eds), Taylor \& Francis Group, London, pp. 943951.

[22] Myers, N.(1997), Environmental Refugees: Population and Environment, 19 (2): 167-82.

[23] Myers, N. and Kent, J. (1995), Environmental Exodus: An Emergent Crisis in the Global Arena. Climate Institute, Washington DC.

[24] Saint, Willam S. and Goldsmith, Willam W. (1980), Cropping Systems Structural Changeand Rural- Urban Migration in Brazil, 8 (1), World Development Press Ltd.

[25] Sarker, M. H., Hugue, I., Alam, M. and Koudstaul, R., (2003), Rivers, Chars and Char Dwellers of Bangladesh, Int. J. of River Basin Management, 1 (1): 61-80.

[26] Shami, S. (1993), The Social Implications of Population
Displacement and Resettlement: An Overview with a Focus on the Arab Middle East. International Migration Review. Vol 27, No 1. pp. 4-33.

[27] Siddiqui, T. (2010), Climate Change and Human Insecurity: Migration as an Adaptation Strategy. Refugee and Migratory Movement Research Unit, Dhaka University, Bangladesh.

[28] Stern, N. (2006), The Economics of Climate Change. Cambridge University Press, UK.

[29] Tanjinul, H. M. and Jannatul, F. (2015), Riverbank Erosion, Population Migration and Rural vulnerability in Bangladesh (A case study on Kazipur Upazila at Sirajgonj district). Environment and Ecology Research 3 (5): 125-131.

[30] Thorne, C. R., (1982), Processes and Mechanisms of River Bank Erosion, In Gravel-bed Rivers, Hey, R. D., Thorne, C. R., Bathurst, J. C. (eds), John Wiley \& Sons, Chichester, pp. 227-271.

[31] Walsham, M. (2010), Assessing the Evidence: Environment, Climate Change and Migration in Bangladesh: Internationa Organization for Migration, Dhaka, Bangladesh. 